\title{
Expression of the homeo box-containing gene En-2 delineates a specific region of the developing mouse brain
}

\author{
Claytus A. Davis, Sandra E. Noble-Topham, Janet Rossant, and Alexandra L. Joyner. \\ Division of Molecular and Developmental Biology, Mount Sinai Hospital Research Institute; Department of Medical \\ Genetics, University of Toronto, Toronto, Ontario, Canada
}

\begin{abstract}
We have examined the pattern of expression of the homeo box-containing gene En-2 during mouse embryogenesis using in situ hybridization. Transcripts were first detected in the neural folds of 8.0-day, 5somite embryos, and expression continued throughout development into adulthood. Hybridization occurred only in the central nervous system (CNS) and was limited to one band of the neural tube and to parts of those structures that later developed from it; the cerebellum, pons, periaqueductal gray, and colliculi. Expression in the germinal zone of the CNS was uniform within the hybridizing band. However, later in development, once cells had migrated out of the germinal zone, there was a reduction in the extent of hybridization and an increase in its spatial complexity. In the adult, expression of En-2 appeared to be limited to specific groups of neurons. The early, localized expression of En-2 within an apparently homogeneous tissue is consistent with the hypothesis that $E n-2$ plays a role in defining a spatial domain within the developing brain.
\end{abstract}

[Key Words: Homeo box; engrailed; RNA in situ; mouse development; brain]

Received November 24, 1987; revised version accepted February 8, 1988.

A number of genes have been isolated from vertebrates by virtue of their homology with the conserved homeo box sequence (McGinnis et al. 1984c; Scott and Weiner, 1984) of many Drosophila pattern formation genes (e.g., Carrasco et al. 1984; Levine et al. 1984; McGinnis et al. 1984a). Because of the importance of the homeo boxcontaining genes in regulating Drosophila development (reviewed by Gehring 1985, 1987) and the conservation and widespread phylogenetic distribution of the homeo box sequence (McGinnis et al. 1984b; Holland and Hogan 1986), it is plausible that these genes play an important role in vertebrate development. In mammals, there are few mutations that are known to affect specific developmental processes. Investigating the expression and function of the mammalian homeo box-containing genes may provide insight into the genetic control of mammalian embryogenesis.

Genomic clones of two mouse genes, En-1 and En-2 (Joyner et al. 1985; Joyner and Martin 1987) were isolated previously on the basis of their homology to the Drosophila segmentation genes engrailed and invected (Poole et al. 1985; Coleman et al. 1987). cDNA clones representing the major transcripts of the two mouse genes were also obtained (Joyner and Martin 1987). The regions of these clones containing homology with engrailed and invected were sequenced and found to include an engrailed-type homeo box, as well as all but 10 bp of the conserved sequences flanking the homeo box in engrailed and invected. Northern blot analysis revealed that the major $3.7-\mathrm{kb}$ En-2 transcript was ex- pressed in undifferentiated and differentiated teratocarcinoma cells and in the whole embryo samples tested (9.5-17.5 days of gestation). This transcript was further localized to the back half of the brain in 12.5-day and 17.5-day embryos and neonatal mice.

If $E n-2$ plays a role in mammalian pattern formation and differentiation, as do the Drosophila homeo boxcontaining genes, one would expect its expression to be similarly spatially restricted in otherwise homogenous tissues during development (e.g., Hafen et al. 1984; Kornberg et al. 1985). In this paper we have used in situ hybridization to demonstrate that the En-2 transcript is expressed in a restricted area of the developing central nervous system (CNS) from 8 days of gestation to adulthood, consistent with a role in specification of brain development.

Results

Experimental strategy

To make a probe specific to the $3.7-\mathrm{kb}$ transcript of En-2, a 260-bp BgIII/SstI fragment of the 3'-untranslated region of the 3.0-kb cDNA clone En-2c (Joyner and Martin 1987) was subcloned into the SP6 transcription vectors pGEM-1 and pGEM-2 (Fig. 1). In a Northern blot analysis of mouse embryo RNA, this fragment detected a single 3.7-kb brain-specific transcript (Fig. 1). To ensure that approximately equal amounts of RNA were in each lane, the blot was rehybridized to a labeled mouse $\beta$-actin 


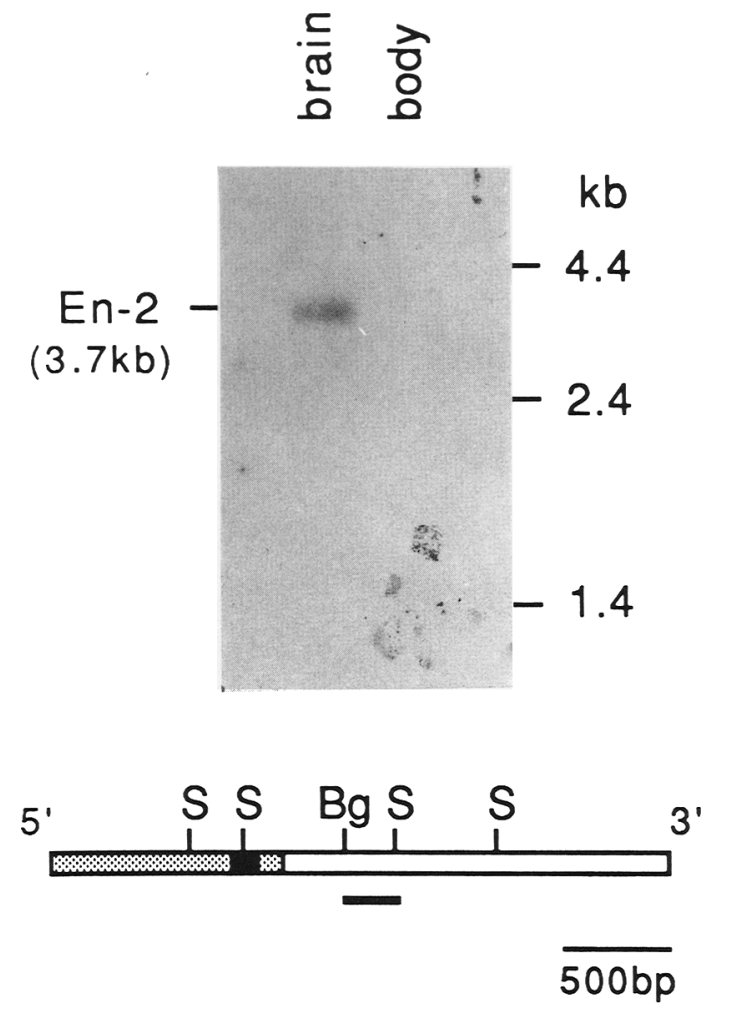

Figure 1. Detection of the $3.7-\mathrm{kb}$ transcript in 17.5-day mouse brains. A Northern blot of poly $(A){ }^{+}$RNA $(1 \mu \mathrm{g})$ isolated from 17.5-day mouse embryo brains and bodies (brain and skull excluded) was analyzed by hybridization to the 250-bp BgIII/ SstI fragment from the En-2 cDNA used in the in situ analysis. This fragment is underlined in the schematic diagram of the En-2 cDNA clone at the bottom of the figure. The shading indicates translated sequence, the open box represents 3 ' untranslated sequence, and the solid box indicates the homeo box. $(\mathrm{S})$ Sst I; (Bg) BgIII restriction enzyme sites.

cDNA probe (data not shown). When the entire $3.0-\mathrm{kb}$ En-2 cDNA was used previously as a probe in a Northern blot analysis, two smaller transcripts were detected in 15.5- to 17.5-whole mouse embryos (Joyner and Martin 1987). Further Northern blot analysis using fragments of the En-2 cDNA as probes demonstrated that the small transcripts are not from En-2 but are highly abundant, skin-specific transcripts that contain a small region $(\sim 500 \mathrm{bp})$ of homology with the En-2 cDNA $5^{\prime}$ of the homeo box and conserved sequences. This was confirmed by isolating cDNA clones for the skin-specific transcripts and comparing their sequence and restriction maps with the En-2 cDNA and genomic clones (data not shown). The En-2 gene therefore appears to generate only a single $3.7-\mathrm{kb}$ transcript. In this study, sense and antisense SP6 transcripts labeled with $\left[{ }^{35}\right.$ S]UTP were produced from the two subclones. These were hybridized to sections of mouse embryos, the sense transcripts serving as a negative control.

Whole mouse embryos between 7.5 and 15.5 days of gestation and brains from 17.5-day embryos and neonatal, and adult mice were examined. Because of the ra- pidity with which developmental events occur just after implantation, the embryos examined between 7.5 and 8.5 days were carefully staged. In all of the stages examined, no specific hybridization was observed when the sense transcript was used, although occasionally the edges of the embryo and lining of some lumens showed higher background than other tissues. The results for the different embryos or tissues, the numbers examined, and their developmental stages are summarized in Table 1.

Table 1. Summary of in situ hybridization to En-2 during mouse embryogenesis

\begin{tabular}{|c|c|c|}
\hline $\begin{array}{l}\text { Developmental } \\
\text { stage }\end{array}$ & $\begin{array}{l}\text { Number of } \\
\text { samples } \\
\text { (number of } \\
\text { sections) }\end{array}$ & Hybridization \\
\hline $\begin{array}{l}7.4 \text { days, primitive } \\
\text { streak, no neural } \\
\text { plate }\end{array}$ & $9(>50)$ & none \\
\hline $\begin{array}{l}7.6 \text { days, neural } \\
\text { plate, no foregut } \\
\text { pocket }\end{array}$ & $11 \mid>50)$ & none \\
\hline $\begin{array}{l}7.7 \text { days, foregut } \\
\text { pocket, no } \\
\text { somites }\end{array}$ & $12(>50)$ & none \\
\hline $\begin{array}{l}8.0 \text { days, } 5-6 \\
\text { somites }\end{array}$ & $8 \mid>50)$ & $\begin{array}{l}\text { band of neural } \\
\text { plate in region of } \\
\text { foregut pocket }\end{array}$ \\
\hline $\begin{array}{l}8.5 \text { days, } \sim 12 \\
\text { somites }\end{array}$ & $8(>50)$ & ring of neural tube \\
\hline $\begin{array}{l}9.0 \text { days, } \sim 16 \\
\text { somites }\end{array}$ & $4(>50)$ & $\begin{array}{l}\text { ring of neural tube } \\
\text { at level of } \\
\text { metencephalon }\end{array}$ \\
\hline 12.5 days & $4(29)$ & $\begin{array}{l}\text { ring of neural tube } \\
\text { at level of } \\
\text { metencephalon }\end{array}$ \\
\hline 15.5 days & $1(25)$ & $\begin{array}{l}\text { developing } \\
\text { cerebellum, parts } \\
\text { of pons, } \\
\text { periaqueductal } \\
\text { gray, and } \\
\text { colliculi }\end{array}$ \\
\hline 17.5-day brain & $2(41)$ & $\begin{array}{l}\text { developing } \\
\text { cerebellum, parts } \\
\text { of pons, } \\
\text { periaqueductal } \\
\text { gray, and } \\
\text { colliculi }\end{array}$ \\
\hline Neonatal brain & $2(51)$ & $\begin{array}{l}\text { similar to above, } \\
\text { but pontine, } \\
\text { periaqueductal } \\
\text { gray and } \\
\text { collicular } \\
\text { hybridization } \\
\text { weakening }\end{array}$ \\
\hline Adult brain & $1(14)$ & $\begin{array}{l}\text { cerebellum, some } \\
\text { pontine but no } \\
\text { periaqueductal } \\
\text { gray or pontine } \\
\text { signal }\end{array}$ \\
\hline
\end{tabular}


Expression of En-2 was first detected in the neural folds during formation of the early somites

To examine En-2 expression during early development, embryos from several time points between 7.5 and 8.5 days of gestation were isolated, separated into stages according to morphological features, and hybridized in situ to the En-2 probe. The three earliest stages examined, between the formation of the primitive streak and the formation of the foregut pocket, but before the formation of somites (see Table 1), showed no specific hybridization with the antisense En-2 probe /results not shown). The first hybridization was seen at day 8.0 , by which time there were five to six pairs of somites. The hybridization was intense and restricted to the cells within a small band of the neural folds anterior to the foregut pocket (Figs. 2a and 3c). The time interval between the last stage, when En-2 expression was not detected, and the first stage when it could be, was approximately $6 \mathrm{hr}$.

En-2 expression was limited to the region of the CNS that develops into the cerebellum, pons, periaqueductal gray, and colliculi

Despite the complex morphogenesis that occurs during development of the CNS, En-2 transcripts were detected at the same position along the axis of the CNS throughout development (Figs. 2-6). Sagittal sections of 8.0-day embryos (Fig. 2a) showed expression of En-2 limited to a small stretch of the neural tube anterior to the foregut pocket. Transverse sections of embryos at the same stage demonstrated that the entire width of the fold expressed the gene in this region (Fig. 3c). By day8.5 , the neural tube was closed where hybridization occurred, and some of the features of the developing brain could be distinguished. All of the cells of the neural tube near the junction of the future hindbrain and midbrain expressed En-2 (Fig. 3d-f). In 12.5-day embryos, hybridization occurred in the same region of the developing brain (Fig. 2c), and transverse sections (Fig. 4b,c) confirmed that an entire ring of the CNS was expressing En-2. By 12.5 days of gestation, embryogenesis was advanced enough to identify which structures of the brain would later develop from the hybridizing areas. In midsagittal sections (Fig. 2c), the isthmus where the colliculi and part of the periaqueductal gray later form, the metencephalon where the cerebellum later forms, and the developing pons all express En-2. By day 17.5, these different structures are clearly recognizable (Fig. 5a), and although the hybridization pattern was more complex in the 17.5-day (Fig. 5), neonatal (Fig. 6), and adult brains (data not shown), En-2 expression was still confined to those regions identified at 12.5 days of gestation.

With the exception of the 12.5-day embryos, none of the embryos examined (8.0-15.0 days) showed any evidence of expression of En-2 in any tissue other than the small region of the developing brain described. In the 12.5-day embryos, occasional faint hybridization was seen around Rathke's pouch, which will form part of the pituitary. Because this was not seen consistently in all of the 12.5-day embryos examined, it may represent an artifact of hybridization.

\section{Expression of En-2 was uniform within the germinal zone}

Histogenesis in the brain follows a distinctive pattern. The layer of cells closest to the lumen of the neural tube is known as the germinal zone. The cells in this layer divide continuously, eventually producing either postmitotic neurons or glioblasts that migrate out of the germinal zone into the cell-sparse region around the outer surface of the neural tube. Here, they form a layer of more loosely packed cells known as the intermediate zone. During the course of development, the germinal zone first increases in thickness, as germinal cells generate more germinal cells, and then decreases in thickness, as neurons and glia form and move out of the zone. The region of the CNS that hybridized to En-2 before 12.5 days, consisted almost entirely of germinal zone cells. By 12.5 days there was a readily apparent intermediate zone (Figs. $2 \mathrm{c}$ and $4 \mathrm{c}$ ) in the region of hybridization. In all the later stages, the germinal zone in the region of hybridization had almost disappeared (Fig. $5 \mathrm{a}, \mathrm{c}$ ) and was quite mitotically inactive.

Within the germinal zone, a band or ring of tissue expressed En-2. The rostral and caudal boundaries of expression were at right angles to the axis of the neural tube in the 9.0- and 12.5-day embryos (Fig. 2). All of the cells of the germinal zone inside these boundaries appeared to express the transcript uniformly, within the limits of resolution provided by ${ }^{35} \mathrm{~S}$. There was a steep gradient in signal intensity at the rostral and caudal boundaries of hybridization in the germinal zone.

\section{The pattern of expression was complex outside the germinal zone}

In contrast to the germinal zone, the spatial pattern of expression in the neurons and glioblasts that have moved out of the germinal zone became increasingly complex. The first indication of this was apparent in the 12.5-day embryos. By this time, cells that have migrated out of the germinal zone to form the intermediate zone can be distinguished in the region of hybridization (Figs. $2 \mathrm{c}$ and $4 \mathrm{c}$ ). In most regions where the germinal zone showed hybridization to En-2, the cells of the overlying intermediate zone also expressed the gene (Fig. 4c). However, this continuity of expression was broken at several places on the edges of the hybridizing region. Two clusters of strongly hybridizing intermediate zone cells interspersed with nonhybridizing cells extended caudally outside of the hybridizing region on either side of the midline of the pons (Fig. $4 \mathrm{~d}$ ). There was a similar but medial rostral extension of hybridization in the ventral intermediate zone (Fig. 2c). Although not shown here, the reverse situation occurred at the rostral boundary where there were two dorsolateral patches of nonhybridizing intermediate zone cells overlying hybridizing germinal zone.

By 17.5 days, the germinal zone, which was reduced in 
thickness and mitotic activity, showed little hybridization. There was, however, extensive hybridization in the developing cerebellum outside the germinal zone. The external granular layer, a dense cover of still dividing cells on the cerebellum, expressed En-2, as did most of the cells within the cerebellum (Fig. 5a,b). Rostral to the cerebellum and dorsal to the pons, the periaqueductal gray showed strong hybridization (Fig. 5a,b). Moving lat- erally, there was a sharp decrease in the hybridization intensity, possibly coinciding with the border between the periaqueductal gray and the colliculi. The hybridization pattern was most complex in the pons. Generally, the boundaries were similar to those seen in the 12.5day embryo, but the spatial pattern of expression was more complex. There were two clusters of strongly expressing cells situated near the boundary between the
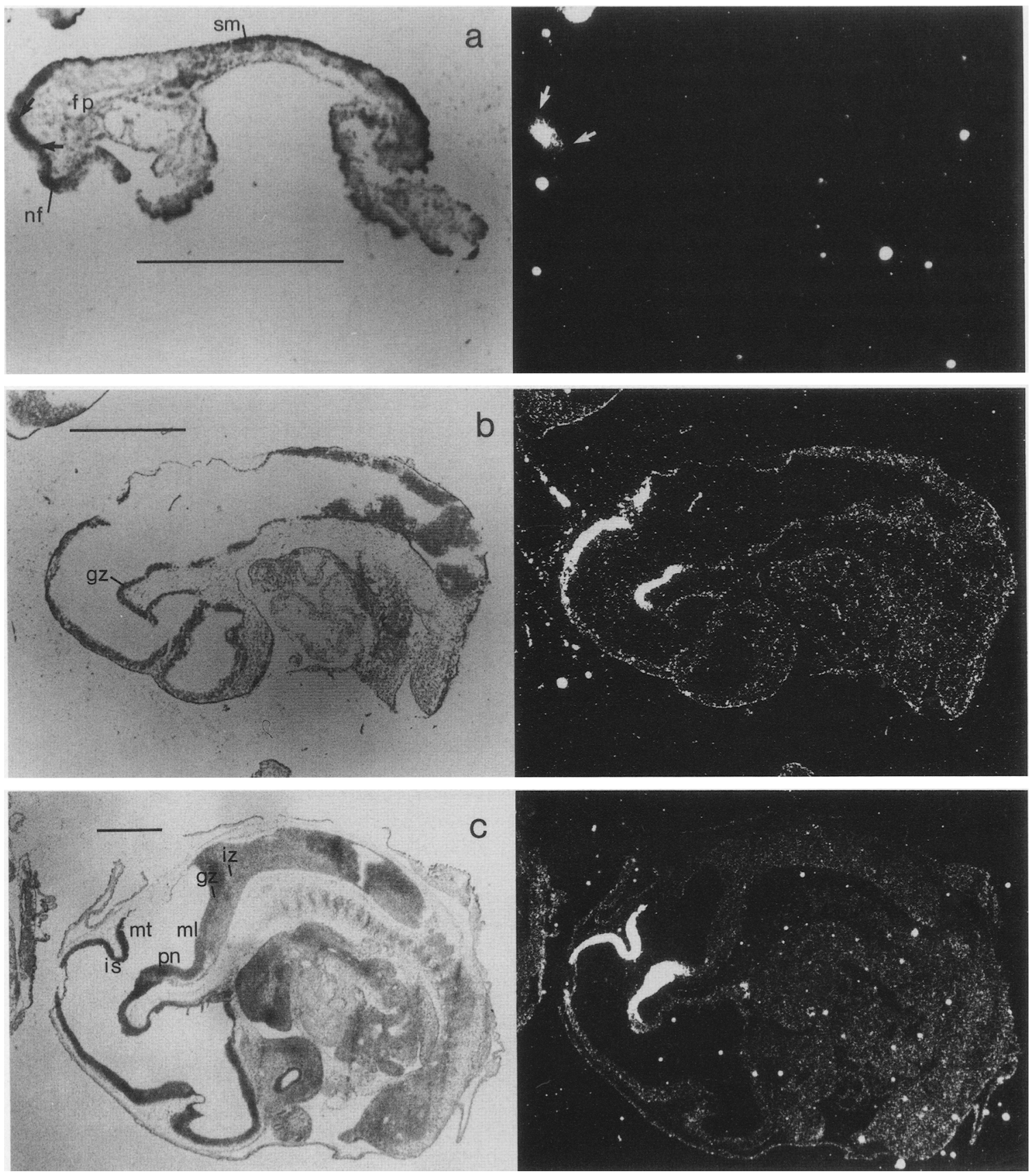

Figure 2. Localization of En-2 transcripts within midsagittal sections of 8.0-, 9.0-, and 12.5-day embryos. Samples were photographed using brightfield illumination (left) to show the morphology and darkfield illumination (right) to show the hybridization. (sm) Somite; (nf) neural fold; (fp) foregut pocket; (gz) germinal zone; (iz) intermediate zone; (is) isthmus; (mt) metencephalon; (pn) pons; (ml) myelencephalon. (a) 8.0-day (5 somites) embryo; (b) 9.0-day (15 somites) embryo; (c) 12.5-day embryo. Scale bars represent $1 \mathrm{~mm}$. 

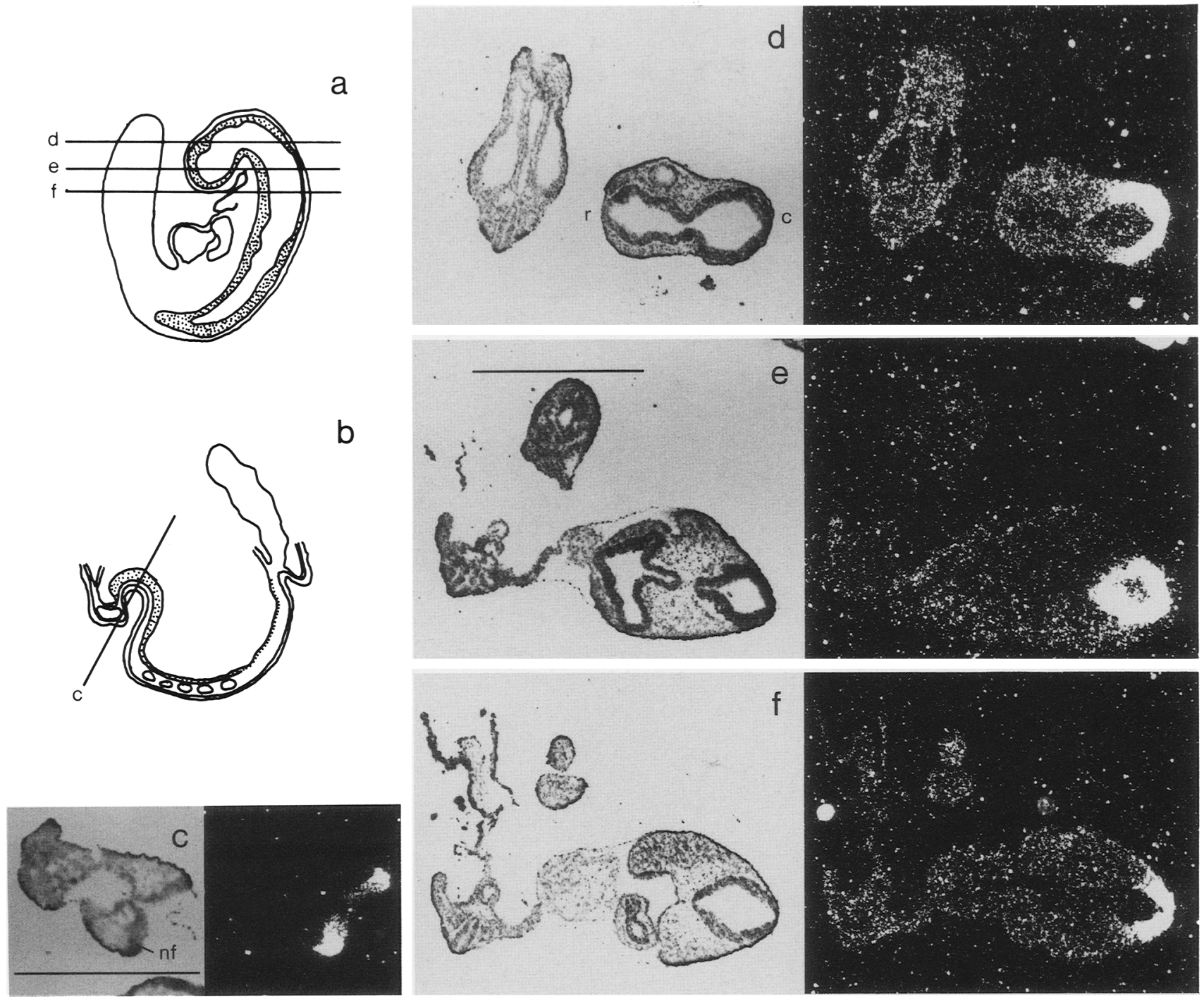

Figure 3. Localization of En-2 transcripts in transverse sections of 8.0- and 8.5-day mouse embryos. (a) Diagram of a midsagittal section of 8.5-day embryo. The stippling indicates the neural tube, and lettered lines mark the level of the transverse sections in $d-f$. (b) Diagram of sagittal section of 8.0-day embryo. Stippling indicates the neural folds, and the lettered line marks the level of the transverse section in $c$. (c) Transverse sections of an 8.0-day (5-somite) embryo at the level indicated in $b$. (nf) Neural fold. $(d-f)$. Transverse sections of an 8.5-day $(\sim 12$ somites) embryo at the levels indicated in $a$. $(\mathrm{r})$ Rostral; (c) caudal. Scale bars represent 1 mm.

cerebellum and pons (Fig. 5b). These may be the same cells that formed two rostral extensions of hybridization in the 12.5-day pons and likely correspond to the developing trigeminal motor nuclei. Rostral to the cerebellum, the hybridization extended from the ventral periaqueductal gray into the pons where it extended further ventrally and rostrally (Fig. $5 \mathrm{c}$ ).

The pattern of hybridization in the neonatal brain was similar to that in the 17.5-day brain. Both the cerebellum and periaqueductal gray were heavily labeled (Fig. 6a,b) although there appeared to be some reduction in signal intensity from the rostral hybridization in the latter and from the caudal edge in the pons when compared with the 17.5-day brain (Fig. 5). Rostral to the cerebellum, the pontine hybridization patterns were similar to those observed in the 17.5-day pons, although the sec- tions shown in Figures $5 c$ and $6 c$ appear different because they are from slightly different positions.

Expression of En-2 was detected in the adult brain, although to a lesser extent (data not shown). In the cerebellum, the cells of the granular layer hybridized intensely, whereas the neighboring Purkinje neurons, the only efferent neurons of the cerebellar cortex, did not. There also appeared to be a scattering of hybridizing cells in the layer closest to the surface of the cerebellum, the molecular layer. In other regions of the brain, hybridization followed a similar pattern to that seen in the 17.5-day and neonatal brain, except that no hybridization could be seen in the periaqueductal gray or colliculi. Preliminary analysis shows that specific groups of neurons in the pons express the gene, although further work is required to identify them. 
Davis et al.

\section{Discussion}

The mammalian homeo box-containing genes may play a critical role in controlling mammalian development. The mouse genes En-1 and En-2 contain a homeo box and flanking sequences homologous to those of the Drosophila engrailed and invected genes (Joyner and Martin 1987). In this study we have determined the pattern of expression of the En-2 gene during embryogenesis. Localized En-2 expression was first detected in the neural

a
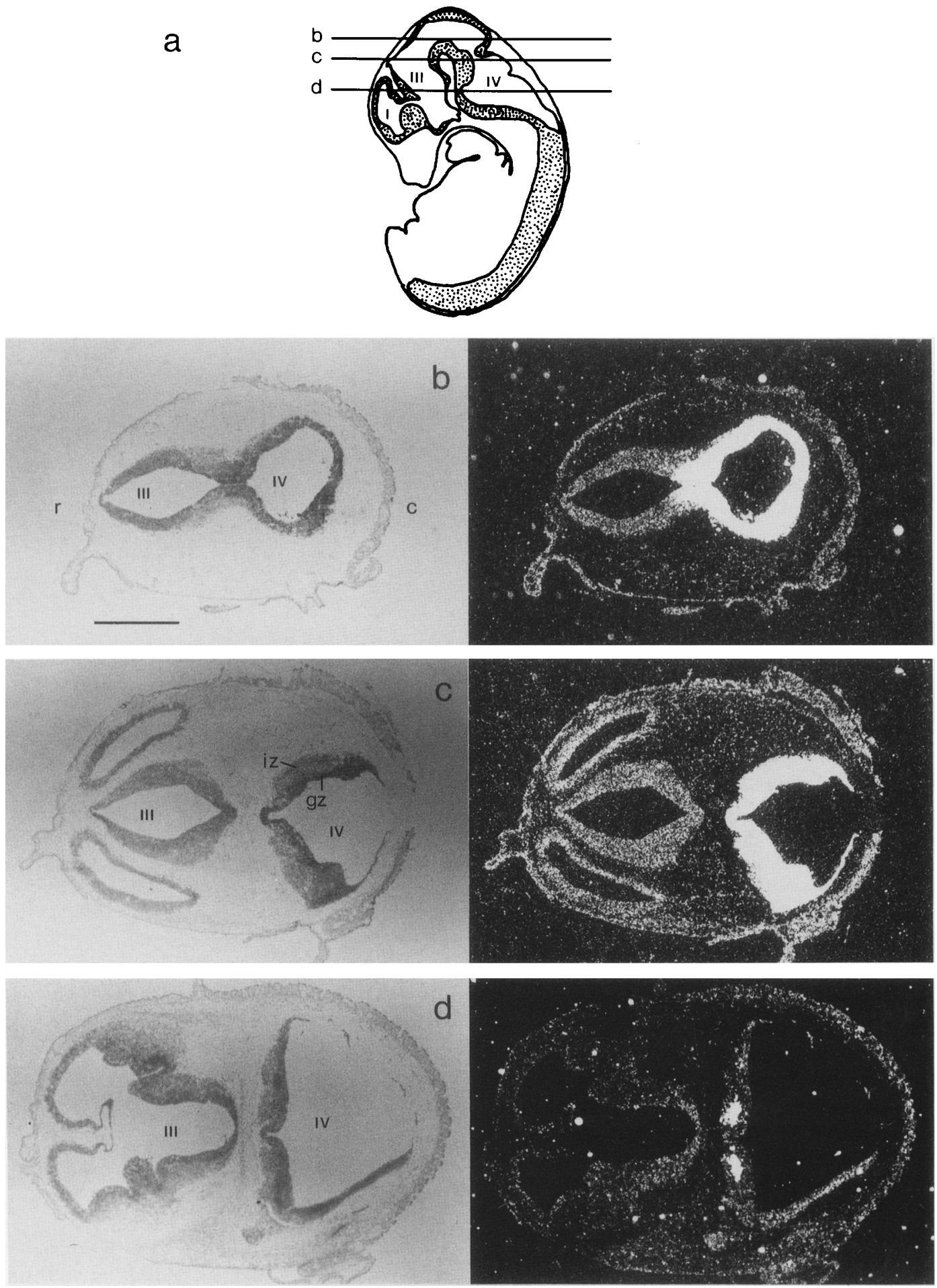

Figure 4. Localization of En-2 transcripts in transverse sections of a 12.5-day mouse embryo. (a) Diagram of a midsagittal section of a 12.5-day mouse embryo. The CNS is stippled. The lettered lines indicate the levels of the transverse sections in $(b-d)$. (I) First ventricle; (III) third ventricle; (IV) fourth ventricle. $(b-d)$. Transverse sections of a 12.5-day mouse embryo at the levels indicated in $a$. Scale bar and labels are the same as those in Figs. 2 and 3. 
folds anterior to the foregut pocket at the 5-6 somite stage. We cannot exclude the possibility that $E n-2$ is expressed earlier at low levels in primitive ectoderm cells because expression of $E n-2$ was detected previously in teratocarcinoma cells (Joyner and Martin 1987), which have many properties in common with primitive ectoderm cells (Martin 1980). The same region of the CNS continued to express En-2 throughout development, and by day 12.5 , it was apparent that the cerebellum, pons, periaqueductal gray, and colliculi arise from this hybridizing area. Within this region of the CNS, there were two distinct spatial patterns of expression. Early in development, expression in the germinal zone appeared to be uniform in a ring, with a steep gradient in signal intensity at the rostral and caudal boundaries of hybridization. Later, the distribution of En-2 transcripts became
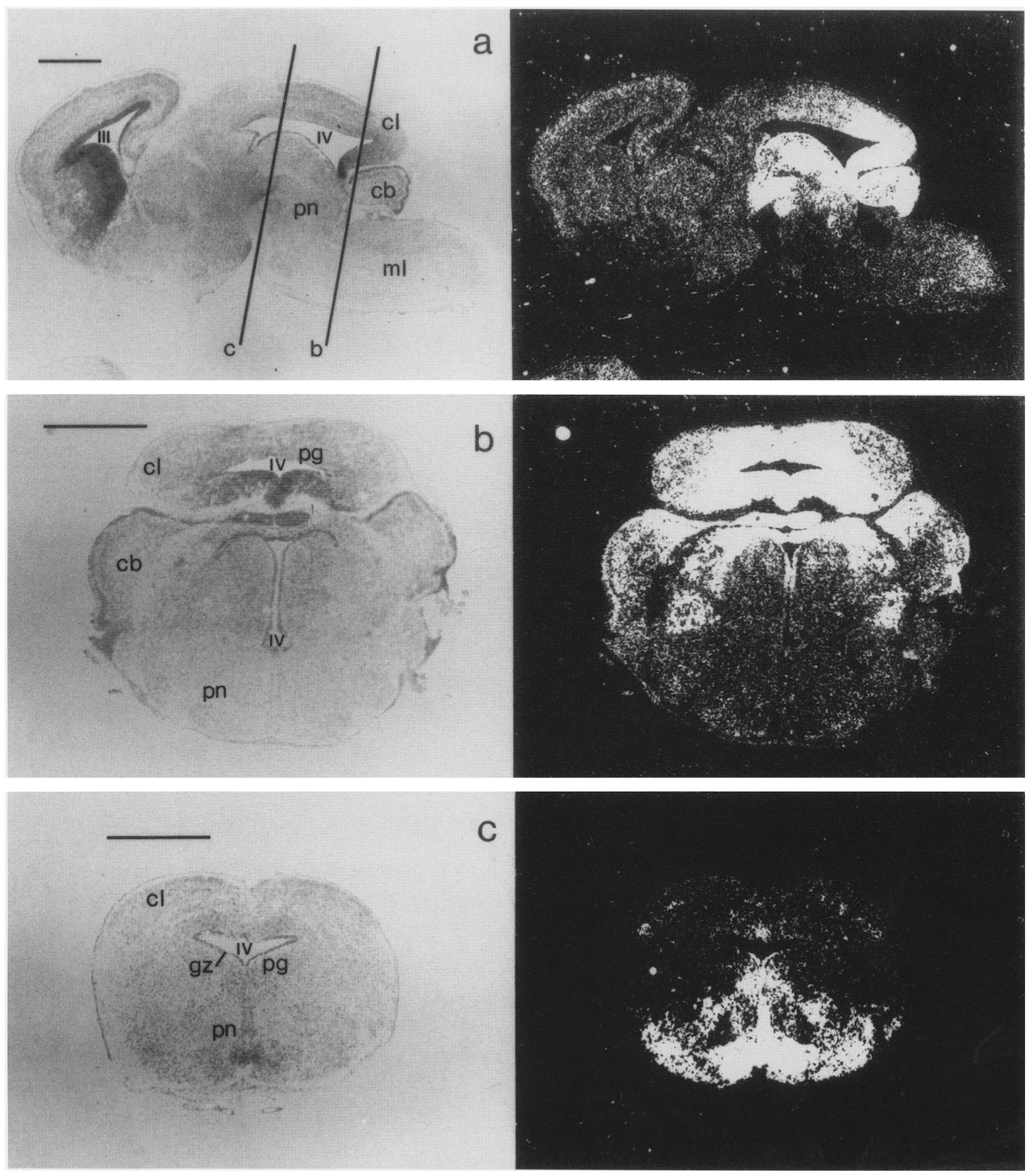

Figure 5. Localization of En-2 transcripts in 17.5-day mouse brains. (a) Midsagittal section of a 17.5-day mouse brain. (III) Third ventricle; (IV) fourth ventricle; (cl) colliculi and periaqueductal gray; (ml) myelencephalon; (cb) cerebellum. Scale bars and other labels are the same as those in Fig. 2. The vertical lines indicate the positions of the coronal sections in $b-c$. $(b-c)$. Coronal sections of a 17.5-day mouse brain at the positions indicated in $a$. (cl) Colliculi; (pg) periaqueductal gray; (hc) hippocampus. 
quite complex in the cells of the brain that had become either glioblasts or neurons and migrated away from the germinal zone. In the adult cerebellum, which is involved in motor control, the Purkinje neurons did not express $E n-2$, whereas the cells of the granular layer did. In the neonatal pons, periaqueductal gray, and colliculi, the domain of En-2 expression appeared to be reduced, and in the adult, expression could not be detected in the periaqueductal gray or colliculi. However, some groups of cells in the pons hybridized as intensely in the adult and neonate as in the 17.5-day embryo.

One of the more interesting features of the profile of En-2 expression during embryogenesis is the transition from uniform expression in the early germinal zone to the complex pattern seen in the 17.5-day, neonatal, and adult brains. The increasing complexity was first apparent in the 12.5-day embryos, where there was mismatched hybridization between the germinal zone and the overlying intermediate zone along the rostral and caudal hybridization boundaries (Figs. $2 \mathrm{c}$ and $4 \mathrm{~d}$ ). The mismatches could have several causes. First, they may be due to migration of cells in the intermediate zone, a process that occurs widely in the developing brain. Second, where expressing intermediate zone cells overlie nonexpressing germinal zone cells, it is possible that En-2 transcription was initiated in cells of the intermediate zone that were not the progeny of expressing germinal zone cells. The reverse situation, nonexpressing intermediate zone over expressing germinal zone, could be accounted for by continued expression of
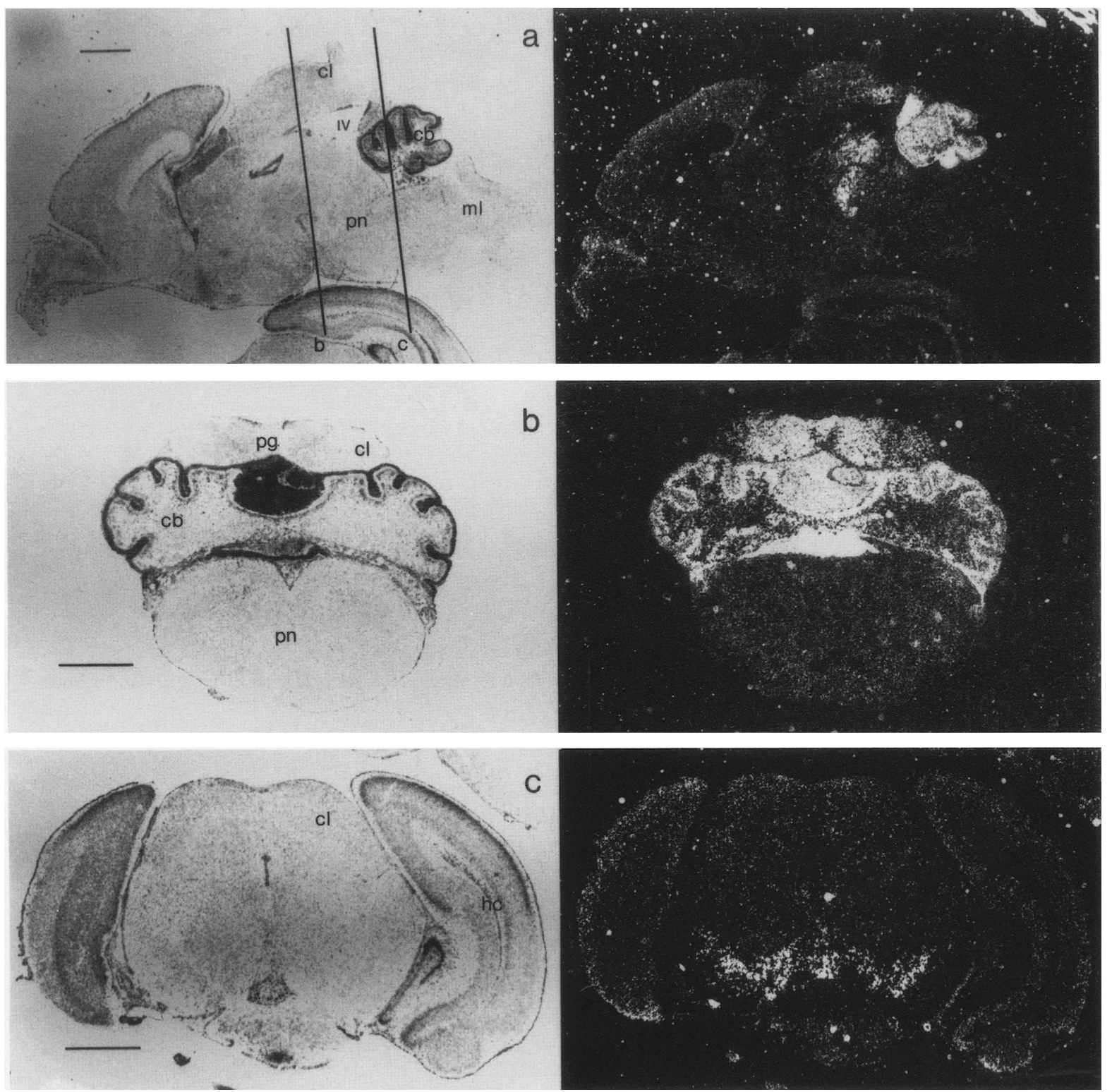

Figure 6. Localization of En-2 transcripts in neonatal mouse brains. (a) Midsagittal section of a neonatal mouse brain. The vertical lines indicate the levels of the sections in $b-c$. The labels are the same as those in Fig. $2(b-c)$. Coronal sections of a neonatal brain at the levels indicated in $a$. 
En-2 in only a subset of the neurons and glioblasts that arose from expressing germinal cells. This latter point is supported further by the apparent reduction in the domain of expression in the pons and periaqueductal gray in the neonate and its complete absence from the latter in the adult.

In Drosophila, the homeo box-containing genes play an important role in many of the processes of development, including determination of embryo polarity, formation of the segments, and establishment of their identities (reviewed in Gehring 1987). In many cases, they are expressed in a spatially restricted manner before there is any apparent cell differentiation. The engrailed and invected genes of Drosophila are expressed in the cellular blastoderm in bands of cells that will form the posterior compartments of the segments and, during later embryogenesis, in the posterior compartments of many of the imaginal discs (Kornberg et al. 1985; Coleman et al. 1987) and in a subset of the neurons arising primarily from the posterior compartments of the blastoderm (DiNardo et al. 1985; Ingham et al. 1985; Coleman et al. 1987). Analyses of wing imaginal discs of engrailed wild-type mosaic flies have shown that engrailed plays a role in the maintenance of the anterior/ posterior compartment boundary and, to a lesser extent, in establishing the unique characteristics of the posterior compartment cells (Garcia-Bellido and Santamaria 1972; Lawrence and Morata 1976). A similar analysis has shown that engrailed is also required for proper development of some regions of the adult brain (Lawrence and Johnston 1984). Unlike engrailed and invected in Drosophila, En-2 in mouse does not show any repeated pattern of expression in the developing embryo and so probably does not function in any metameric or segmentation processes that occur during mouse development. However, there are similarities between the expression pattern of engrailed and invected in Drosophila and that of $E n-2$ in the mouse. Most important, $E n-2$ is expressed early in a spatially restricted domain of an otherwise undifferentiated tissue. In addition, like engrailed and invected, En-2 is expressed in a subset of cells in the developing nervous system.

Information about the expression of a number of different murine homeo box-containing genes (Hox; Martin et al. 1987) is accumulating. All of the Hox genes analyzed to date have been shown to be expressed in embryos. In situ RNA hybridization analyses of sections of early embryos have localized this expression to specific spatial domains within the spinal cord and hindbrain and in the somitic or lateral plate mesoderm (Awgulewitsch et al. 1986; Gaunt et al. 1986; Dony and Gruss 1987; Gaunt 1987; Holland and Hogan 1987; Krumlauf et al. 1987; Toth et al. 1987). As development proceeds, expression continues in the same or more restricted regions of the CNS and can be detected in the mesodermal layers of various internal organs. The expression pattern of En-2 shows some similarities to that of the Hox genes. Expression was found in the developing CNS and was first detected in the neural folds just before or during the formation of the first somites, as was observed with Hox-1.5 (Fainsod et al. 1987; Gaunt 1987) and Hox-2.1 (Holland and Hogan 1987). However, there are a number of differences. The region of hybridization to En-2 was much more restricted within the CNS than any of the Hox genes and no expression was detected in any nonneuronal tissues. En-2 expression occurs entirely within the brain and defines a more rostral region of the developing CNS than any of the Hox genes examined to date. In the adult, it is possible that a complementary pattern of expression of En-2 and Hox -1.3 exists in the cerebellum. Antibodies raised to the Hox-1.3 protein bound to the Purkinje neurons but not to the granular neurons (Odenwald et al. 1987). This is the reverse of the pattern shown by En-2.

The early time and pattern of expression of the mouse Hox genes is consistent with their playing a crucial role in determining the characteristics of the CNS by defining and maintaining spatial domains within this tissue. The localization of En-2 transcripts throughout development is consistent with the hypothesis that it also plays such a role and extends the potential action of the homeo box class of genes more rostrally into the brain. The pattern of expression of En-2 in the late embryonic stages and adult brain opens the possibility that it may be involved in specification of different cell populations in the brain. It is interesting to note that the distribution of a subset of the catecholaminergic neurons in the developing rat brain (Specht et al. 1981a,b) is similar to the distribution of some of the En-2-expressing cells that we observed during mouse embryogenesis. Future studies combining the use of antibodies to specific classes of neurons and glia and antibodies to the En-2 protein should provide more detailed information on the cells that express En-2 in the brain.

\section{Methods}

Northern blot analysis

All procedures were similar to those described by Joyner et al. (1985) except that total cellular RNA was isolated from 17.5day mouse embryo brains or bodies (brain and skull excluded) using a modified $\mathrm{LiCl}$ /urea procedure (Shackleford and Varmus 1987). One microgram of each poly(A) ${ }^{+}$RNA sample was fractionated by electrophoresis in an agarose gel and transferred to a nylon membrane (GeneScreen, Dupont). Hybridization was performed at $63^{\circ} \mathrm{C}$ for $18 \mathrm{hr}$ in hybridization buffer containing $350 \mathrm{~mm} \mathrm{Na} \mathrm{HPO}_{4}, 1 \mathrm{mM}$ EDTA, $7 \%$ SDS, $1 \% \mathrm{BSA}$, and $25 \%$ formamide. The final wash was at $65^{\circ} \mathrm{C}$ in $30 \mathrm{mM} \mathrm{Na}_{2} \mathrm{HPO}_{4}$ and $0.1 \%$ SDS. The 260-bp BgIII/SstI En-2 cDNA was isolated from the pGEM vector on an agarose gel and radiolabeled to a specific activity of $4.2 \times 10^{9} \mathrm{dpm}$ using a modified random priming procedure (Feinberg and Vogelstein 1983).

\section{In situ analysis}

Sample preparation. Embryos from outbred CD-1 mice (Charles River) were collected between days 7.5 and 17.5 of gestation and removed from the uterus (the midpoint of the dark interval during which plugging occurred was considered day 0 ). All samples were immersed fresh in OCT medium (Tissue-Tek) 
and frozen in a small beaker of hexanes in a dry ice-EtOH bath. Samples were stored at $-70^{\circ} \mathrm{C}$ and sectioned within 2 months. To remove RNase contamination, the glassware and slides were baked at $160^{\circ} \mathrm{C}$ for $4 \mathrm{hr}$, and all solutions were made up in DEPC-treated water. Sections of the embryos or brains were cut at $7 \mu \mathrm{m}$ on a cryostat microtome, collected on poly-L-lysinecoated slides and immediately placed on a glass plate at $-70^{\circ} \mathrm{C}$ for $>30 \mathrm{~min}$. The sections were immersed, still frozen, in a fresh solution of $4 \%$ paraformaldehyde for $4 \mathrm{~min}$ and acetylated with $0.25 \%$ acetic anhydride added fresh to $100 \mathrm{~mm}$ triethanolamine ( $\mathrm{pH} 7.5$ ). The slides were rinsed in $3 \times$ phosphate-buffered saline (PBS) for $5 \mathrm{~min}$ and twice in $1 \times$ PBS for $3 \mathrm{~min}$, dehydrated through an ethanol series $(30 \%, 55 \%, 80 \%, 95 \%)$ for 3 min each, and air-dried. They were stored desiccated at $-70^{\circ} \mathrm{C}$ for up to 3 months without any detectable signal loss.

Probe preparation. To prepare the SP6 templates, the two pGEM plasmids containing the 260-bp BglII/SstI fragment of the En-2 cDNA were linearized at the insert/vector junction with an appropriate restriction enzyme. Transcripts were made from the SP6 promoter following the protocol of Promega-Biotech. For each $1 \mu \mathrm{g}$ of template, $100 \mu \mathrm{Ci}$ of [ ${ }^{35}$ S|UTP /Amersham, $410 \mathrm{Ci} / \mathrm{mmole} /$ was used in a reaction volume of $20 \mu \mathrm{l}$. Transcripts were precipitated and washed with EtOH to remove the unincorporated nucleotides. Incorporation of the labeled nucleotides was consistently over $90 \%$. The quality of the transcription reaction was checked on a polyacrylamide sequencing gel. The probes were kept at $-20^{\circ} \mathrm{C}$ in $1 \mathrm{M}$ dithiothreitol (DTT) and used within a month.

Hybridization. The hybridization mix contained $50 \%$ formamide, $0.3 \mathrm{M} \mathrm{NaCl}, 10 \mathrm{~mm}$ Tris- $\mathrm{HCl}$ (pH 7.5), $1 \mathrm{~mm}$ EDTA, $1 \times$ Denhardt's solution, $250 \mu \mathrm{g} / \mathrm{ml}$ tRNA, $250 \mu \mathrm{g} / \mathrm{ml}$ sheared heterologous DNA, $10 \%$ dextran sulphate, $100 \mathrm{mM}$ DTT, and 0.2 $\mu \mathrm{g} / \mathrm{ml} /\left(\mathrm{kb}\right.$ of complexity) of ${ }^{35} \mathrm{~S}$-labeled probe. Fifty microliters of hybridization mix was applied to each section. Coverslips were placed on the slides, which were then incubated between two sealed pieces of parafilm at $37^{\circ} \mathrm{C}$ for $5-24$ hours.

Washes. After hybridization, the slides were placed in $2 \times$ SSC-10 mM $\beta$-mercaptoethanol, and the coverslips were allowed to fall off. They were then shaken gently at room temperature in the $2 \times$ SSC- $10 \mathrm{mM} \beta$-mercaptoethanol for 15 minutes, $2 \times$ SSC $-10 \mathrm{~mm} \beta$-mercaptoethanol- $1 \mu \mathrm{g} / \mathrm{ml}$ RNase A for $10 \mathrm{~min}, 2 \times \mathrm{SSC}-10 \mathrm{~mm} \beta$-mercaptoethanol for $30 \mathrm{~min}$, $0.1 \times \mathrm{SSC}-10 \mathrm{mM} \beta$-mercaptoethanol at $65^{\circ} \mathrm{C}$ for $30 \mathrm{~min}$ and, finally, $0.1 \times$ SSC- $10 \mathrm{~mm} \beta$-mercaptoethanol at $65^{\circ} \mathrm{C}$ for 60 min. The sections were dehydrated in $70 \% \mathrm{EtOH}, 0.3 \mathrm{M} \mathrm{am}$ monium acetate and 95\% EtOH, $0.3 \mathrm{M}$ ammonium acetate for 5 min each and left to air-dry.

Exposure. The slides were exposed to X-ray film for 3-4 days to test for successful hybridization. Slides were then dipped in Kodak NTB-2 emulsion diluted $1: 1$ with $0.6 \mathrm{M}$ ammonium acetate at $45^{\circ} \mathrm{C}$, left to dry for a few hours, and then placed in slide boxes with desiccant at $-70^{\circ} \mathrm{C}$. Exposure time was between 30 and 45 days. Slides were developed at $16^{\circ} \mathrm{C}$ in freshly made half-strength Kodak D19 developer, rinsed briefly in water, fixed with Kodak fixer, and rinsed for at least $10 \mathrm{~min}$ in running water. The sections were stained in $0.5 \%$ Toluidine Blue- $10 \mathrm{~mm}$ sodium acetate $(\mathrm{pH} 4.6)$ for $10 \mathrm{~min}$, rinsed quickly in water, dehydrated through three changes of acetone, acetone : xylene $(1: 1)$ and, finally, in xylene for $5 \mathrm{~min}$. The slides were then mounted in Permount.

Photography. All photographs were taken using Kodak technical pan film 2415 at an ASA of 100 on a Leitz macroscope.

\section{Acknowledgments}

We would like to thank Dr. Derek van der Kooy for his assistance in analyzing the expression pattern in the late embryo, neonatal, and adult brains and Dr. Karen Downs for her efforts in the initial stages of this project. This work was supported by grants from the Medical Research Council (MRC) of Canada (A.J. and J.R.), the Natural Sciences and Engineering Research Council of Canada (A.J. and J.R.), and the National Cancer Institute of Canada (NCI) (J.R.). A.J. is an MRC Scholar and J.R. is an NCI Research Associate. C.D. was supported by an Ontario graduate scholarship and an MRC studentship and S.N.-T. was supported by an MRC studentship.

\section{References}

Awgulewitsch, A., M.F. Utset, C.P. Hart, W. McGinnis, and F.H. Ruddle. 1986. Spatial restriction in expression of a mouse homeo box locus within the central nervous system. Nature 320: 328-335.

Carrasco, A.E., W. McGinnis, W.J. Gehring, and E.M. De Robertis. 1984. Cloning of an $X$. laevis gene expressed during early embryogenesis coding for a peptide region homologous to Drosophila homeotic genes. Cell 37: 409-414.

Coleman, K.G., S.J. Poole, M.P. Weir, W.C. Soeller, and T. Kornberg. 1987. The invected gene of Drosophila: Sequence analysis and expression studies reveal a close kinship to the engrailed gene. Genes Dev. 1: 19-28.

DiNardo, S., J.M. Kuner, J. Theis, and P.H. O'Farrell. 1985. Development of embryonic pattern in $D$. melanogaster as revealed by accumulation of the nuclear engrailed protein. Cell 43: 59-69.

Dony, C. and P. Gruss. 1987. Specific expression of the hox-1.3 homeo box gene in murine embryonic structures originating from or induced by the mesoderm. EMBO I. 6: 2965-2975.

Fainsod, A., A. Awgulewitsch, and F.H. Ruddle. 1987. Expression of the murine homeo box gene Hox-1.5 during embryogenesis. Dev. Biol. 124: 125-133.

Feinberg, A.P. and B. Vogelstein. 1983. A technique for radiolabeling DNA restriction endonuclease fragments to high specific activity. Anal. Biochem. 132: 6-13.

Garcia-Bellido, A. and P. Santamaria. 1972. Developmental analysis of the wing disc in the mutant engrailed of Drosophila melanogaster. Genetics 72: 87-104.

Gaunt, S.J. 1987. Homoeobox gene Hox-1.5 expression in mouse embryos: Earliest detection by in situ hybridization is during gastrulation. Development 101: 51-60.

Gaunt, S.J., J.R. Miller, D.J. Powell, and D. Duboule. 1986. Homoeobox gene expression in mouse embryos varies with position by the primitive streak stage. Nature 324: 662-664.

Gehring, W. 1985. The homeo box: A key to the understanding of development? Cell 40: 3-5.

- 1987. Homeo boxes in the study of development. Science 236: 1245-1252.

Hafen, E., A. Kuroiwa, and W. Gehring. 1984. Spatial distribution of transcripts from the segmentation gene fushi tarazu during Drosophila embryonic development. Cell 37: 833841.

Holland, P.W.H. and B.L.M. Hogan. 1986. Phylogenetic distribution of Antennapedia-like homoeo boxes. Nature 321: $251-253$.

. 1987. Spatially restricted patterns of expression in the homeobox-containing gene Hox2.1 during mouse embryogenesis. Dev. Biol. (in press).

Ingham, P.A., A. Martinez-Arias, P. Lawrence, and K. Howard. 1985. Expression of engrailed in the parasegments of Drosophila. Nature 317: 634-636. 
Joyner, A.L. and G.R. Martin. 1987, En-1 and En-2, two mouse genes with sequence homology to the Drosophila engrailed gene: Expression during embryogenesis. Genes Dev. 1: 29-38.

Joyner, A.L., T. Kornberg, K.G. Coleman, D.R. Cox, and G.R. Martin. 1985. Expression during embryogenesis of a mouse gene with sequence homology to the Drosophila engrailed gene. Cell 43: 29-37.

Kornberg, T., I. Siden, P. O'Farrell, and M. Simon. 1985. The engrailed locus of Drosophila: In situ localization of transcripts reveals compartment-specific expression. Cell 40: 45-53.

Krumlauf, R., P.W.H. Holland, J.H. McVey, and B.L.M. Hogan. 1987. Developmental and spatial patterns of expression of the mouse homeobox gene, Hox2.1. Development 99: 603617.

Lawrence, P.A. and P. Johnston. 1984. On the role of the en grailed $^{+}$gene in the internal organs of Drosophila. EMBO J. 3: $2839-2844$.

Lawrence, P.A. and G. Morata. 1976. Compartments in the wing of Drosophila: A study of the engrailed gene. Dev. Biol. 50: 321-337.

Levine, M., G.M. Rubin, and R. Tjian. 1984. Human DNA sequences homologous to a protein coding region conserved between homeotic genes of Drosophila. Cell 38: 667-673.

Martin, G.M. 1980. Teratocarcinomas and mammalian embryogenesis. Science 209: 768-776.

Martin, G.R., E. Boncinelli, D. Duboule, P. Gruss, I. Jackson, R. Krumlauf, P. Lonai, W. McGinnis, F. Ruddle, and D. Wolgemuth. 1987. Nomenclature for homoeo-box-containing genes. Nature 325: 21-22.

McGinnis, W., C.P. Hart, W.J. Gehring, and F.H. Ruddle. 1984a. Molecular cloning and chromosome mapping of a mouse DNA sequence homologous to homeotic genes of Drosophila. Cell 38: 675-680.

McGinnis, W., R.L. Garber, H. Wirz, A. Kuroiwa, and W.J. Gehring. 1984b. A homologous protein-coding sequence in Drosophila homeotic genes and its conservation in other metazoans. Cell 37: 403-408.

McGinnis, W., M.S. Levine, E. Hafen, A. Kuroiwa, and W.J. Gehring. 1984c. A conserved DNA sequence in homoeotic genes of the Drosophila Antennapedia and bithorax complexes. Nature 308: 428-433.

Odenwald, W.F., C.F. Taylor, F.J. Palmer-Hill, V. Friedrich, Jr., M. Tani, and R.A. Lazzarini. 1987. Expression of a homeo domain protein in noncontact-inhibited cultured cells and postmitotic neurons. Genes Dev. 1: 482-496.

Poole, S.J., L.M. Kauvar, B. Drees, and T. Kornberg. 1985. The engrailed locus of Drosophila: Structural analysis of an embryonic transcript. Cell 40: 37-43.

Scott, M.P. and A.J. Weiner. 1984. Structural relationships among genes that control development: Sequence homology between the Antennapedia, Ultrabithorax, and fushi tarazu loci of Drosophila. Proc. Natl. Acad Sci. 81: 4115-4119.

Shackleford, G.M. and H.E. Varmus. 1987. Expression of the proto-oncogene int-1 is restricted to postmeiotic male germ cells and the neural tube of mid-gestational embryos. Cell 50: 89-95.

Specht, L.A., V.M. Pickel, T.H. Joh, and D.J. Reis. 1981a. Lightmicroscopic immunocytochemical localization of tyrosine hydroxylase in prenatal rat brain. I. Early ontogeny. J. Comp. Neurol. 199: 233-253.

- 1981b. Light-microscopic immunocytochemical localization of tyrosine hydroxylase in prenatal rat brain. I. Late ontogeny. J. Comp. Neurol. 199: 255-261.

Toth, L.E., K.L. Slawin, J.E. Pintar, and M.C. Nguyen-Huu.
1987. Region-specific expression of mouse homeobox genes in the embryonic mesoderm and central nervous system. Proc. Natl. Acad. Sci. 84: 6790-6794. 


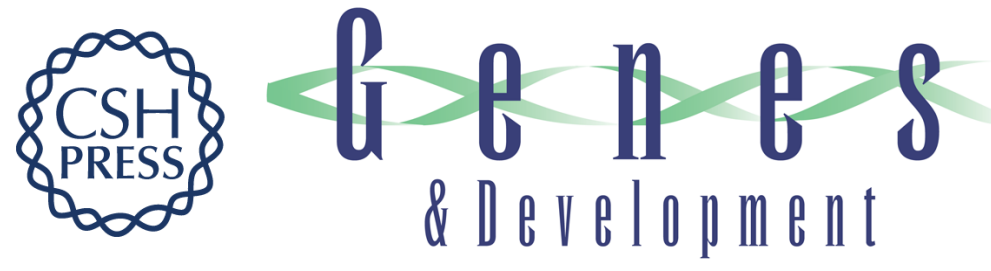

\section{Expression of the homeo box-containing gene En-2 delineates a specific region of the developing mouse brain.}

C A Davis, S E Noble-Topham, J Rossant, et al.

Genes Dev. 1988, 2:

Access the most recent version at doi:10.1101/gad.2.3.361

References This article cites 34 articles, 7 of which can be accessed free at:

http://genesdev.cshlp.org/content/2/3/361.full.html\#ref-list-1

License

Email Alerting

Service

Receive free email alerts when new articles cite this article - sign up in the box at the top right corner of the article or click here.

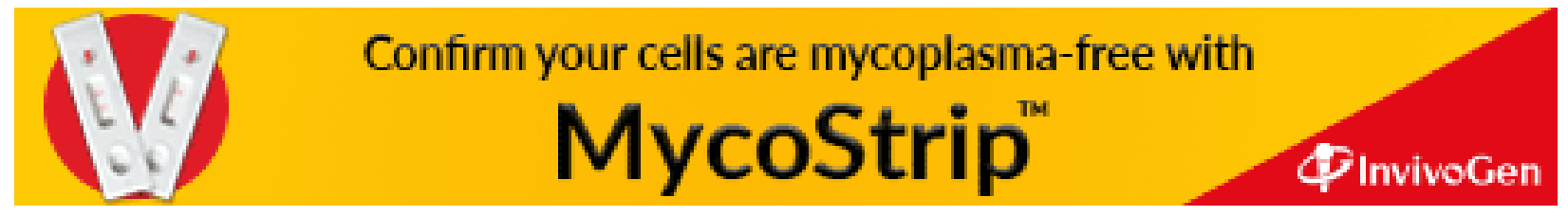

